\title{
Effect of CNTs-Assisted Ball Milling on Morphology and Oxidation Behavior of Zr Powders
}

\author{
Kang Xiaoli ${ }^{1,2}, \quad$ Zhu Guoling ${ }^{2}, \quad$ Yang Fan $^{1}, \quad$ Jiang Xiaodong ${ }^{1}, \quad$ Yi Zao ${ }^{2}, \quad$ Tang \\ Yongjian $^{1}$
}

${ }^{1}$ Research Center of Laser Fusion, China Academy of Engineering Physics, Mianyang 621900, China; ${ }^{2}$ Joint Laboratory for Extreme Conditions Matter Properties, Southwest University of Science and Technology and Research Center of Laser Fusion, CAEP, Mianyang 621900, China

\begin{abstract}
Morphology evolution and oxidation behavior of $\mathrm{Zr}$ powders milled with and without CNTs for different time were compared. XRD and SEM were used to determine the phase composition and morphology of obtained $\mathrm{Zr}$ and $\mathrm{Zr} / \mathrm{CNTs}$ powders. Thermogravity (TG) analysis was applied to evaluate the thermal oxidation behavior of $\mathrm{Zr}$ and $\mathrm{Zr} / \mathrm{CNTs}$. Results show that the phase composition of $\mathrm{Zr}$ after milling is not influenced by adding CNTs, but the morphology and oxidation behavior of $\mathrm{Zr}$ are influenced. In case of milling without CNTs, particle size of $\mathrm{Zr}$ continues to reduce from more than $10 \mu \mathrm{m}$ to about $2 \sim 3 \mu \mathrm{m}$ when milling time increases from $1 \mathrm{~h}$ to $3 \mathrm{~h}$. In case of CNTs-assisted milling, the particle size reduction of $\mathrm{Zr}$ is not obvious until milling time is prolonged to $3 \mathrm{~h}$. This is because those CNTs adhered on the surface of $\mathrm{Zr}$ or CNTs-induced agglomerations among $\mathrm{Zr}$ prohibit the mechanical impact and fracturing effects of milling balls on $\mathrm{Zr}$ particles. Compared with direct milling of $\mathrm{Zr}$, when the obtained $\mathrm{Zr}$ has similar particle size, adding CNTs lowers the onset oxidation temperature and peak exothermic temperature of $\mathrm{Zr}$ powders by $11 \sim 37^{\circ} \mathrm{C}$, depending on milling time. This is ascribed to the high heat conductivity of CNTs which favors heat transfer between $\mathrm{Zr}$ particles. At the same time, oxidative mass gain of $\mathrm{Zr} / \mathrm{CNTs}$ is slightly lower than that of the corresponding pure $\mathrm{Zr}$ when milling time is less than $2 \mathrm{~h}$ and then this trend reverses. The initial decrease in mass gain of $\mathrm{Zr}$ in $\mathrm{Zr} / \mathrm{CNTs}$ mixtures under shorter milling time is related to two factors: one is CNTs-induced agglomerations of $\mathrm{Zr}$, which prohibits the contact of $\mathrm{Zr}$ with oxygen and thus decreases the degree of oxidation, and the other is the delayed particle size reduction of $\mathrm{Zr}$ in $\mathrm{Zr} / \mathrm{CNTs}$ mixtures. The subsequent reversal in mass gain for pure $\mathrm{Zr}$ and $\mathrm{Zr} / \mathrm{CNTs}$ is due to the positive effect of particle size reduction of $\mathrm{Zr}$ in $\mathrm{Zr} / \mathrm{CNTs}$ on its thermal oxidation just began, while the spontaneous oxidation-induced negative effect for well-refined pure $\mathrm{Zr}$ has become very obvious.
\end{abstract}

Key words: Zr powders; CNTs; ball milling; morphology; oxidation

Metal $\mathrm{Zr}$ has the advantages of high volumetric heat of combustion heat $\left(77.77 \mathrm{~kJ} / \mathrm{cm}^{3}\right)$, moderate ignition temperature $\left(200 \sim 400{ }^{\circ} \mathrm{C}\right)$ and good burning stability. These advantages make $\mathrm{Zr}$ powder an important component in energetic materials such as propellants and pyrotechnics ${ }^{[1-5]}$. Previous studies demonstrated that ignition and combustion properties of pure $\mathrm{Zr}$ and $\mathrm{Zr}$-containing energetic compositions could be significantly influenced by particle sizes or types of $\mathrm{Zr}$. Lee ${ }^{[6]}$ found that $\mathrm{Zr}$ powders having fine particles $(1 \sim 5 \mu \mathrm{m})$ and low purity (>94\%) showed higher auto-ignition temperature $\left(312{ }^{\circ} \mathrm{C}\right.$ vs. $\left.298{ }^{\circ} \mathrm{C}\right)$ and activation energy of decomposition $(77.9 \mathrm{~kJ} / \mathrm{mol}$ vs. $70.1 \mathrm{~kJ} / \mathrm{mol})$ than $\mathrm{Zr}$ powders having coarse particles $(1 \sim 23 \mu \mathrm{m})$ and high purity (>97\%). Also, thermal behavior of $\mathrm{Zr} / \mathrm{KClO}_{4}$ compositions with these two types of $\mathrm{Zr}$ powders varied. C. Badiola ${ }^{[7]}$ investigated ignition characteristics of microsized $(50 \mu \mathrm{m})$ and nanosized $(50 \sim 70 \mathrm{~nm}) \mathrm{Zr}$ powders. Results showed that nanosized $\mathrm{Zr}$ powders had significantly low ignition

Received date: September 09, 2016

Foundation item: National Natural Science Foundation of China (51306165); Open Foundation of Joint Laboratory for Extreme Conditions Matter Properties, Southwest University of Science and Technology and Research Center of Laser Fusion, CAEP (12zxjk01); Science and Technology Foundation of CAEP (2013B0302052)

Corresponding author: Tang Yongjian, Ph. D., Professor, Research Center of Laser Fusion, China Academy of Engineering Physics, Mianyang 621900, P. R. China, E-mail: tangyongjian2000@sina.com

Copyright (C 2017, Northwest Institute for Nonferrous Metal Research. Published by Elsevier BV. All rights reserved. 
temperature (about $150 \sim 200{ }^{\circ} \mathrm{C}$ ) and the ignition time needed under the same heating power was shortened by several times. Therefore, tuning the reactivity of $\mathrm{Zr}$ powders to match different requirements is an important aspect in developing high-performance $\mathrm{Zr}$-containing propellants and pyrotechnics. Besides changing the particle sizes or types of $\mathrm{Zr}$, there are other solutions such as introducing external components to alter reactivity of $\mathrm{Zr}^{[8,9]}$.

Recently, carbon nanotubes (CNTs) have been applied in energetic materials to modify the performance of either the pure energetic component or the energetic compositions. For example, as the initiator of the photo-acoustic effect, CNTs could realize optical ignition of energetic systems ${ }^{[10]}$; as the catalysts or catalyst support, CNTs could promote the thermal decomposition of $\mathrm{NH}_{4} \mathrm{ClO}_{4}^{[11,12]}$ or $\mathrm{RDX}^{[13,14]}$; as the flammable fuels, CNTs could react with oxidizer such as $\mathrm{KNO}_{3}$ to produce high temperature ${ }^{[15]}$; as the additives, CNTs could control electrostatic discharge ignition sensitivity of composite energetic materials ${ }^{[16]}$, delay performance of pyrotechnic delay composition ${ }^{[17]}$ and thermal oxidation behavior of Al powders ${ }^{[18]}$. Particularly, the Ref. [18] reported that oxidation behavior of $\mathrm{Al}$ powders varied with the morphologies of Al/CNTs mixture, while morphologies of Al/CNTs mixture could be engineered by controlling milling time. This result may provide a new way to tailor oxidation of metal powders other than Al. However, there has been no more report on such kind of investigations.

In the present work, morphology evolution and thermal oxidation of $\mathrm{Zr}$ and $\mathrm{Zr} / \mathrm{CNTs}$ milled for different hours were compared. The objective of this study is to understand the effect of CNTs on the morphology evolution of $\mathrm{Zr}$ during ball milling process and on the thermal oxidation behavior of $\mathrm{Zr}$.

\section{Experiment}

Raw materials of $\mathrm{Zr}$ powders $(38 \mu \mathrm{m})$ were purchased from General Research Institute for Nonferrous Metals, Beijing. CNTs used in this work was purchased from Shenzhen Nanotech Port Co. Ltd and used directly without other processing. They have diameters of 30 40 nm and lengths of a few $\mu \mathrm{m}$. As seen in Fig.1, these CNTs were bent and tangled. $\mathrm{Zr}$ powders with or without CNTs were ball milled in $\mathrm{ZrO}_{2}$ jars under ethyl alcohol protection. Milling balls were $\mathrm{ZrO}_{2}$ balls of $6 \mathrm{~mm}$ in diameter and the ball-to-powder ratio was 10:1 in mass. The content of CNTs in the $\mathrm{Zr} / \mathrm{CNTs}$ mixtures was $1.0 \%$ (wt $\%$ ). Milling jars rotated at $150 \mathrm{r} / \mathrm{min}$ and the direction was reversed every $20 \mathrm{~min}$ with a break of $5 \mathrm{~min}$ in order for cooling. Samples were taken out and dried under vacuum when milling time accumulated to 1,2 , and $3 \mathrm{~h}$. As a reference test, the physical mixture of $\mathrm{Zr}$ and CNTs mixed manually was prepared to compare with the ball milled $\mathrm{Zr} / \mathrm{CNTs}$.

Morphology of $\mathrm{Zr}$ or $\mathrm{Zr} / \mathrm{CNTs}$ powders were characterized by SEM (scanning electron microscopy), and their phase

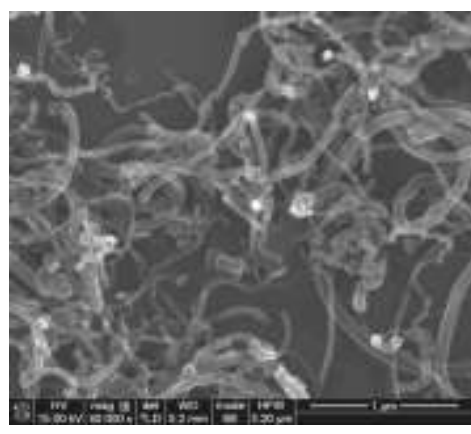

Fig.1 SEM image of CNTs used in this study

structure was analyzed by XRD. Thermogravimetry (TG) measurement was used to study thermal oxidation of $\mathrm{Zr}$ or $\mathrm{Zr} / \mathrm{CNTs}$. In the TG test, powder samples of $2 \mathrm{mg}$ were heated under flowing air atmosphere from room temperature to $1000{ }^{\circ} \mathrm{C}$ at $20^{\circ} \mathrm{C} / \mathrm{min}$.

\section{Results and Discussion}

\subsection{Structure and morphology analysis}

Fig. 2 and Fig. 3 show XRD patterns of pure $\mathrm{Zr}$ and $\mathrm{Zr} / \mathrm{CNTs}$ powders before and after milling, respectively. As seen in Fig.2, with prolonging milling time, peak intensities of the diffraction peaks gradually decrease, accompanied by the slight broadening of peaks, indicating the increasing defects in $\mathrm{Zr}$ particles during milling process. Fig. 3 reveals that all diffraction peaks observed belong to $\mathrm{Zr}$, so there is no new phase produced during CNTs-assisted milling. The diminished
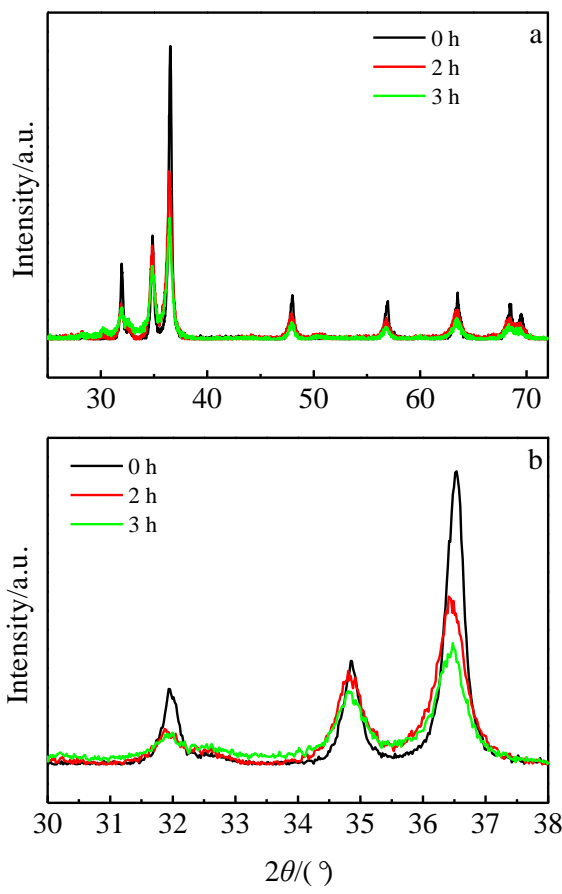

Fig.2 XRD patterns of pure $\mathrm{Zr}$ milled for different time: (a) full pattern and (b) partial enlarged pattern 

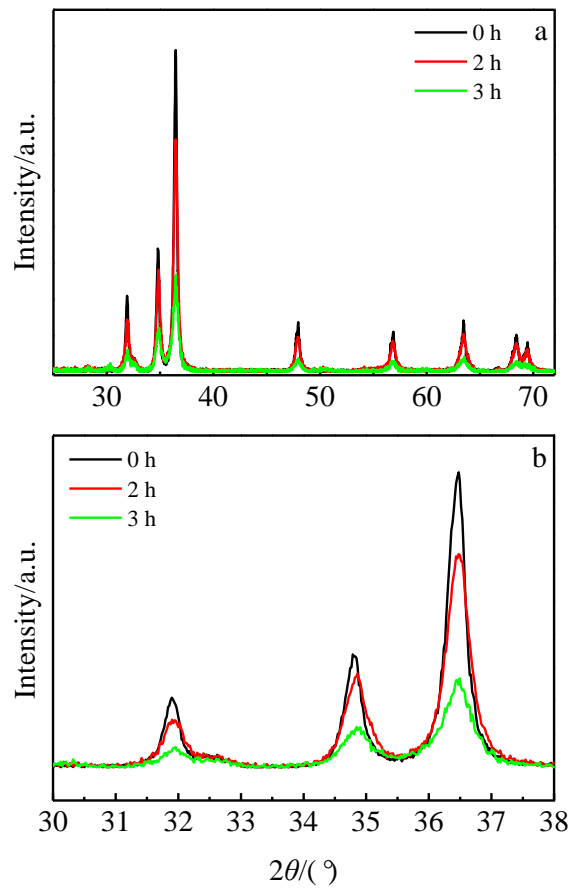

Fig.3 XRD patterns of $\mathrm{Zr} / \mathrm{CNTs}$ milled for different time: (a) full pattern and (b) partial enlarged pattern

diffraction peaks for CNTs in the XRD patterns $\mathrm{Zr} / \mathrm{CNT}$ are probably because the content of CNTs is too low to be detected. The variation trend of peak intensities with milling time for $\mathrm{Zr} / \mathrm{CNT}$ s mixtures is similar to that of pure $\mathrm{Zr}$.

Fig.4 shows SEM images of pure $\mathrm{Zr}$ powders before and after ball milling. As seen in Fig.4a, particle size of raw $\mathrm{Zr}$ powders is not uniform, ranging from $1 \mu \mathrm{m}$ to $20 \mu \mathrm{m}$. Their shape is irregular and the surface is rough. With the prolonging of milling time (Fig.4b, 4c), coarse $\mathrm{Zr}$ particles begin to break into small particles, and these newly generated small $\mathrm{Zr}$ particles tend to adhere on the surface of large particles. After milling for $3 \mathrm{~h}$ (Fig.4d), the mean particle size decreases to $2 \sim 3 \mu \mathrm{m}$, and the particle size distribution becomes more uniform than the short-time milled ones.

Fig.5 presents the morphology of $\mathrm{Zr} / \mathrm{CNTs}$ mixtures obtained by ball milling. It could be observed that after milling for $1 \mathrm{~h}$ (Fig.5a), large agglomerations comprised of tangled CNTs and very fine $\mathrm{Zr}$ particles are formed, and the size of agglomerations ranges from $2 \mu \mathrm{m}$ to $10 \mu \mathrm{m}$. These agglomerations are formed due to the electrostatic force between the CNTs and fine $\mathrm{Zr}$ particles. From the magnified picture in Fig.5b, one could see that the shape and length of CNTs keep nearly unchanged. After milling for $2 \mathrm{~h}$ (Fig.5c, 5d), the size of CNTs-Zr agglomerations decrease a little and the density of CNTs in the clusters also declines, indicating the improved dispersion of CNTs among $\mathrm{Zr}$ powders. When prolonging milling time to $3 \mathrm{~h}$ (Fig.5e, 5f), large agglomerations of

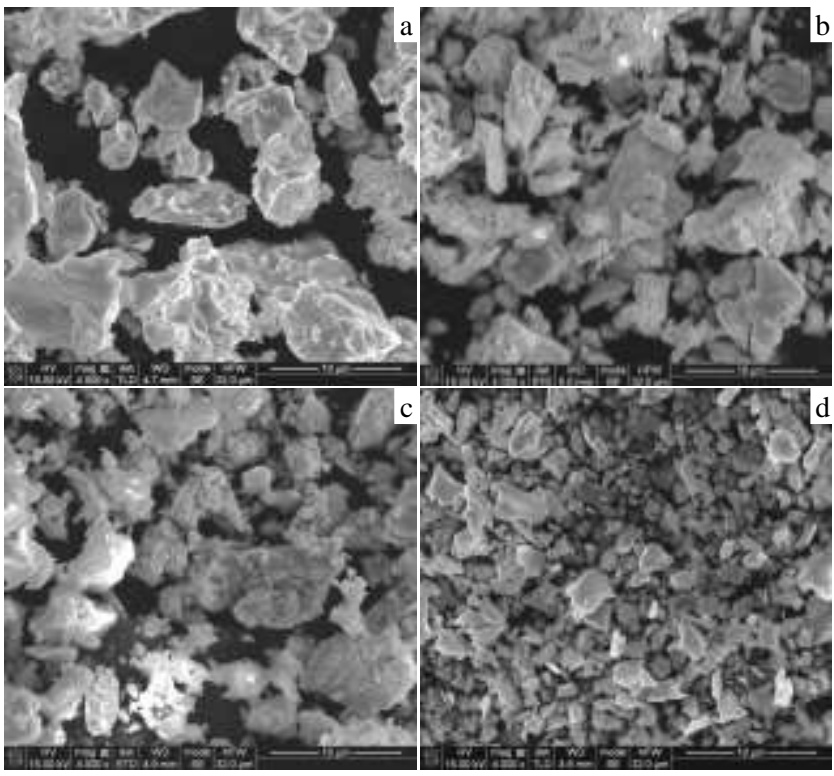

Fig.4 SEM images of pure $\mathrm{Zr}$ powders before milling (a) and after milling for $1 \mathrm{~h} \mathrm{(b),} 2 \mathrm{~h} \mathrm{(c),} \mathrm{and} 3 \mathrm{~h} \mathrm{(d)}$

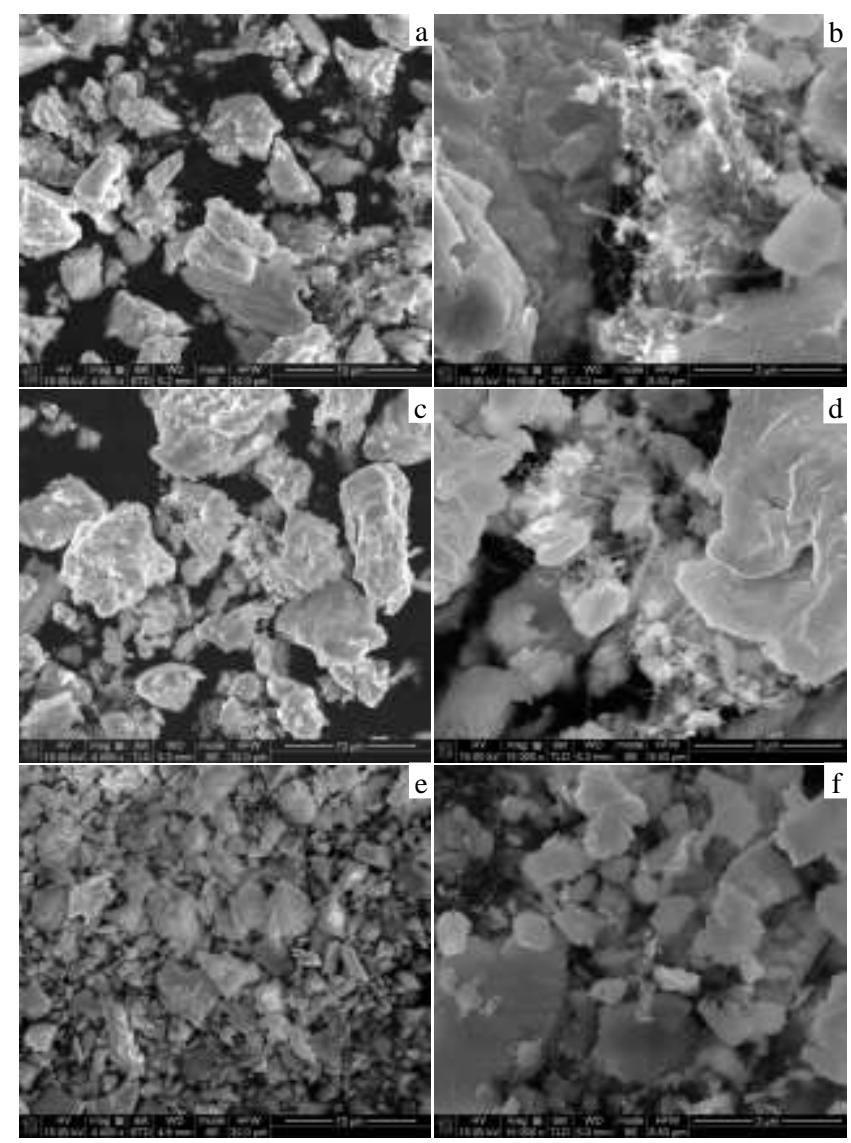

Fig.5 SEM images of $\mathrm{Zr} / \mathrm{CNTs}$ mixtures after milling for $1 \mathrm{~h}(\mathrm{a}, \mathrm{b})$, $2 \mathrm{~h}(\mathrm{c}, \mathrm{d})$, and $3 \mathrm{~h}(\mathrm{e}, \mathrm{f})$ 
$\mathrm{Zr}$ /CNTs disappear, and the dispersion of CNTs in the mixture is further improved. At the same time, some of the CNTs in the mixture are found to be broken or shortened. Maybe due to the damage of CNTs, the binding of CNTs with $\mathrm{Zr}$ particle also changes. Despite those CNTs existing in the gaps of fine $\mathrm{Zr}$ particles, some of the shortened CNTs begin to adhere to the surface of coarse $\mathrm{Zr}$ particles, and some of the CNTs integrate with nano-scale $\mathrm{Zr}$ particles, leading to the increase in their diameter. Compared with the dispersion of CNTs in other metal powders such as $\mathrm{Al}^{[18]}$ and $\mathrm{Mg}^{[19]}$ through mechanical milling processing, the characteristic of CNTs dispersion in Zr powder is that it is difficult to let CNTs insert or embed into the $\mathrm{Zr}$ matrix. This is probably because the ductibility of $\mathrm{Zr}$ is worse than that of the soft metal like $\mathrm{Al}$ and $\mathrm{Mg}$. Therefore, during low speed ball milling of $\mathrm{Zr}$ powders, the brittle fracturing process of coarse particles is dominated, and the plastic deformation is not obvious. Thus, CNTs only adhered on the surface of $\mathrm{Zr}$ or dispersed in the gaps of fine $\mathrm{Zr}$ particles but could not be embedded into the matrix.

In addition to the dispersion of CNTs in $\mathrm{Zr}$ powders, another question need to concern is the effect of adding CNTs on the morphology evolution of $\mathrm{Zr}$ powders. From Fig.4 and Fig.5, we could see that compared with pure $\mathrm{Zr}$ milled for the same time, particle size of $\mathrm{Zr}$ in $\mathrm{Zr} / \mathrm{CNTs}$ mixtures looks larger, especially when milling time is shorter than $3 \mathrm{~h}$. This result is different from the morphology evolution of $\mathrm{Al} / \mathrm{CNTs}^{[18]}$ and $\mathrm{Mg} / \mathrm{CNTs}^{[19]}$, where CNTs as a grinding aid favor the particle size reduction. Probable reasons for this difference are as follows: in case of $\mathrm{Al} / \mathrm{CNTs}$ and $\mathrm{Mg} / \mathrm{CNTs}$, the promoting role of CNTs in particle size reduction occurs under the conditions that CNTs are heterogeneously dispersed and coat the surface of these metal particles, so the agglomeration and cold-welding of metal particles are prevented. However, in case of $\mathrm{Zr} / \mathrm{CNTs}$, as mentioned before, CNTs could not embed into the surface of $\mathrm{Zr}$ particles to form a coating. In contrast, in order to decrease the surface energy of each other, small $\mathrm{Zr}$ particles easily agglomerate with CNTs and form a lot of clusters. The existence of these clusters weakens the mechanical impact of milling ball on coarse $\mathrm{Zr}$ particles, so that the brittle fracturing and refining of $\mathrm{Zr}$ is restricted. When milling time is prolonged to $3 \mathrm{~h}$, the dispersion of CNTs is improved, so the particle size reduction of $\mathrm{Zr}$ becomes obvious.

\subsection{Thermal-gravity analysis}

Fig.6 show TG curves of pure $\mathrm{Zr}$ and $\mathrm{Zr} / \mathrm{CNTs}$ milled for different time. Fig.6a indicate that the onset oxidation temperature of $\mathrm{Zr}$ keeps decreasing when milling time is increased. On the other hand, the total mass gain first increases after milling for $1 \mathrm{~h}$ and then begins to decrease. The decrease in the onset oxidation temperature and the initial increase in mass gain after short-time milling could be easily understood by the particle size effect, which could be
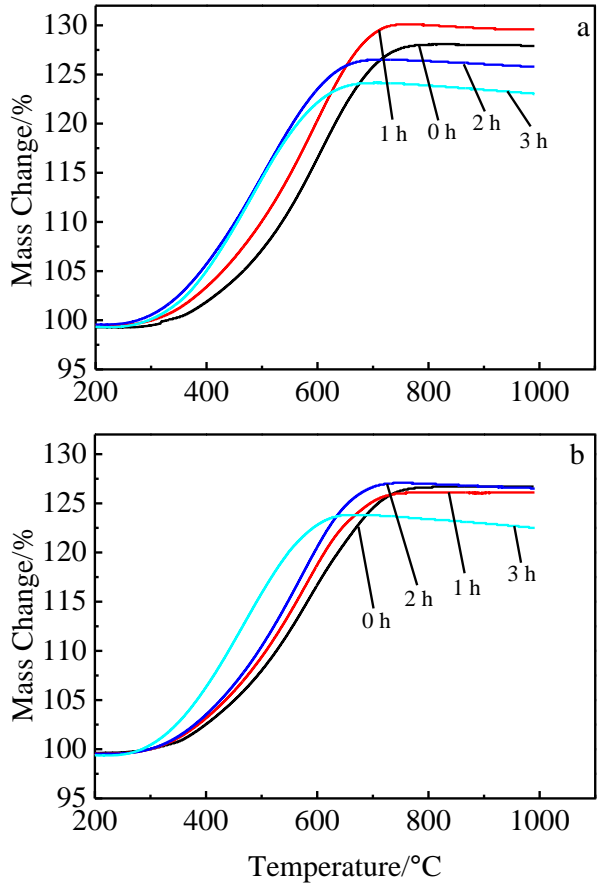

Fig.6 TG curves of pure $\mathrm{Zr}$ (a) and Zr/CNTs (b) milled for different time

supported by the SEM images in Fig.4. While the subsequent reduction in mass gain is probably caused by the unavoidable spontaneous oxidation of fine $\mathrm{Zr}$ powders during milling process, because the ethanol-protection on oxidation during milling is very limited. As seen in Fig.6b, for Zr/CNTs mixtures, the variation of onset oxidation temperature and mass gain shows a similar trend with that of the pure $\mathrm{Zr}$ samples, except the maximum mass gain at the milling time equal to $2 \mathrm{~h}$. This kind of difference in the variation of TG curves in Fig.6b is possibly caused by two reasons: first is the particle size effect of $\mathrm{Zr}$ in the $\mathrm{Zr} / \mathrm{CNTs}$ mixtures during milling process, as mentioned in the SEM results; second is the special effect of CNTs. To declare the potential effect of CNTs, the detailed comparison in characteristic parameters in Fig.6a and Fig.6b are listed in Table 1.

It could be seen in Table 1 that the effect of adding CNTs during milling on the oxidation behavior of $\mathrm{Zr}$ powders is closely related to milling time, as could be reflected in the typical oxidation temperature and oxidative mass gain. Considering that during the heating of $\mathrm{Zr} / \mathrm{CNTs}$ mixtures, the oxidative mass gain of $\mathrm{Zr}$ and the oxidative mass loss of CNTs simultaneously occurred, to strictly compare the degree of oxidation of $\mathrm{Zr}$ powders in the $\mathrm{Zr} / \mathrm{CNTs}$ mixtures, the effect of oxidative mass loss of $1.0 \%$ CNTs was deducted when calculating the mass gain of $\mathrm{Zr}$. It is found that when the milling time is set as 0,1 and $3 \mathrm{~h}$, the onset oxidation temperature in TG curve and peak temperature in DTG curve for $\mathrm{Zr} / \mathrm{CNTs}$ are lower than that for pure $\mathrm{Zr}$. That is, in most 
Table 1 Summary of characteristic parameters obtained from TG curves

\begin{tabular}{|c|c|c|c|c|c|c|}
\hline \multirow{2}{*}{ Time/h } & \multicolumn{2}{|c|}{$T_{\text {onset }} /{ }^{\circ} \mathrm{C}$} & \multicolumn{2}{|c|}{$T_{\text {peak }}$ in DTG $/{ }^{\circ} \mathrm{C}$} & \multicolumn{2}{|c|}{ Mass gain $/ \%$} \\
\hline & $\mathrm{Zr}$ & $\mathrm{Zr} / \mathrm{CNTs}$ & $\mathrm{Zr}$ & $\mathrm{Zr} / \mathrm{CNTs}$ & $\mathrm{Zr}$ & $\mathrm{Zr} / \mathrm{CNTs}$ \\
\hline 0 & 475 & 438 & 601 & 587 & 28.1 & 27.9 \\
\hline 1 & 441 & 430 & 594 & 574 & 30.0 & 27.3 \\
\hline 2 & 367 & 420 & 512 & 573 & 26.5 & 28.3 \\
\hline 3 & 366 & 352 & 484 & 464 & 24.1 & 24.9 \\
\hline
\end{tabular}

cases (except when the milling time is $2 \mathrm{~h}$ ), the addition of CNTs favors the decrease in the oxidation temperature of $\mathrm{Zr}$ powders. This should be ascribed to the good thermal conductivity of CNTs, even though CNTs agglomerate seriously in the $\mathrm{Zr} / \mathrm{CNTs}$ mixtures under short-time milling conditions. On the other hand, the oxidation ratio of $\mathrm{Zr}$ powders under CNTs-assisted milling is first decreased when milling time is shorter than $2 \mathrm{~h}$, and then this trend reverses. By considering the SEM images in Fig. 4 and Fig.5, it is inferred that this adverse effect of adding CNTs on oxidative mass gain of $\mathrm{Zr} / \mathrm{CNTs}$ is related to two factors: (1) CNTs induced agglomeration of small $\mathrm{Zr}$ particles in $\mathrm{Zr} / \mathrm{CNTs}$ mixtures, so that the oxygen diffusion into the inside of $\mathrm{Zr}$ particles is restricted and the active mass of $\mathrm{Zr}$ participated in the oxidation reaction is decreased; (2) after milling for the same time $(1 \mathrm{~h})$, particle size of $\mathrm{Zr}$ in $\mathrm{Zr} / \mathrm{CNTs}$ mixtures is coarser than that of the pure $\mathrm{Zr}$. The second aspect could also explain the abnormal increase in onset oxidation temperature and total mass gain for $\mathrm{Zr} / \mathrm{CNTs}$ milled for $2 \mathrm{~h}$ when compared with its counterpart (seen in Table 1). In detail, though CNTs still play a positive role in the thermal conductivity of heat transfer during oxidation of $\mathrm{Zr}$, when milling time is $2 \mathrm{~h}$, the oxidation reaction of $\mathrm{Zr} / \mathrm{CNTs}$ is more dependent on the particle size of $\mathrm{Zr}$. In this stage, the particle size of pure $\mathrm{Zr}$ has been well refined, but the particle refining of $\mathrm{Zr}$ in $\mathrm{Zr} / \mathrm{CNTs}$ just begins, so the onset oxidation temperature of $\mathrm{Zr} / \mathrm{CNTs}$ is naturally high. At the same time, just because of the finer particle size of pure $\mathrm{Zr}$, its spontaneous oxidation is more serious than the coarse $\mathrm{Zr}$ in the $\mathrm{Zr} / \mathrm{CNTs}$, which causes its lower mass gain than the corresponding $\mathrm{Zr} / \mathrm{CNTs}$. This kind of spontaneous oxidation also exists for the $\mathrm{Zr}$ in $\mathrm{Zr} / \mathrm{CNT}$ mixtures, but it is not obvious until the milling time is prolonged to $3 \mathrm{~h}$.

In a word, the promoting effect of adding CNTs on lowering oxidation temperature of $\mathrm{Zr}$ is noticeable, while the potential adverse effect on decreasing reaction heat caused by agglomeration of CNTs in $\mathrm{Zr} / \mathrm{CNTs}$ mixture needs further resolution.

\section{Conclusions}

1) CNTs-assisted ball milling is not beneficial to the particle size reduction of $Z$ r. After milling for the same time, particle sizes of $\mathrm{Zr}$ in the $\mathrm{Zr} / \mathrm{CNT}$ mixture are larger than the $\mathrm{Zr}$ milled without adding CNTs.

2) CNTs could lower the onset oxidation temperature and peak exothermic temperature of $\mathrm{Zr}$ powders, even when CNTs seriously agglomerate in the $\mathrm{Zr} / \mathrm{CNTs}$ mixtures under short-time milling conditions.

3) Agglomerations of CNTs themselves or agglomerations of $\mathrm{Zr}$ with CNTs are formed during milling, and the restriction effect of CNTs on particle size reduction of $\mathrm{Zr}$ has an adverse influence on the oxidative mass gain of $\mathrm{Zr}$ during thermal oxidation process, which means the potential loss in reaction heat of $\mathrm{Zr}$.

4) It is suggested that by controlling the milling parameters and choosing appropriate size of both $\mathrm{Zr}$ and CNTs to improve the dispersion of CNTs in Zr powders, the adverse effect of CNTs on particle size reduction and oxidation reaction heat of $\mathrm{Zr}$ could be avoided.

\section{References}

1 Alekseev A P, Lempert D B, Nemtsev G G et al. Russian Journal of Physical Chemistry B[J], 2011, 5: 997

2 Lempert D B, Nechiporenko G N, Manelis G B. Combustion, Explosion, and Shock Waves[J], 2011, 47: 45

3 Pourmortazavi S M, Hosseini S G, Hajimirsadeghi S S et al. Combust Sci Tech[J], 2008, 180: 2093

4 Miyata K, Kubota N. Propellants, Explosives, Pyrotechnics[J], 1996, 21: 29

5 Byoung S M, Hyung S H. Journal of Propulsion and Power[J], 2012, 28: 211

6 Lee J S, Hsu C K. Thermochimica Acta[J], 2001, 367-368: 375

7 Badiola C, Dreizin E L. Proceedings of the Combustion Institute [J], 2013, 34: 2237

8 Kuwahara T, Kohno T, Wang C H. Propellants, Explosives, Pyrotechnics[J], 2004, 29: 56

9 Lv B L, Xu Y, Hou B et al. Materials Research Bulletin[J], 2008, 43: 2769

10 Manaa M R, Mitchell A R, Garza R G et al. J Am Chem Soc[J], 2005, 127: 13786

11 Zhang X J, Jiang W, Song D et al. Propellants Explosives Pyrotechnics[J] 2009, 34: 151

12 Cui $\mathrm{P}$, Li F S, Zhou $\mathrm{J}$ et al. Propellants, Explosives, Pyrotechnics[J], 2006, 31: 452

13 An T, Cao H Q, Zhao F Q et al. Acta Phys-Chim $\operatorname{Sin}[\mathrm{J}], 2012$, 28: 2202

14 Ren H, Liu Y Y, Jiao Q J et al. Journal of Physics and Chemistry of Solids[J], 2010, 71: 149

15 Guo R, Hu Y, Shen R Q et al. Chemical Engineering Journal[J], 2012, 211-212: 31

16 Poper K H, Collins E S, Pantoya M L et al. Journal of Electrostatics[J], 2014, 72: 428

17 Ren H, Jiao Q J, Chen S C. Journal of Physics and Chemistry of Solids[J], 2010, 71: 145

18 Jeong H Y, So K P, Bae J J et al. Energy[J], 2013, 55: 1143

19 Chen B H, Kuo C H, Ku J R et al. Journal of Alloys and Compounds[J], 2013, 568: 78 


\title{
CNTs 辅助球磨对 $\mathrm{Zr}$ 粉形貌和氧化性能的影响
}

\author{
康晓丽 ${ }^{1,2}$, 朱国灵 ${ }^{2}$, 杨 帆 $^{1}$, 蒋晓东 ${ }^{1}$, 易 早 $^{2}$, 唐永建 ${ }^{1}$
}

(1. 中国工程物理研究院激光聚变研究中心, 四川绵阳 621900)

(2. 西南科技大学-中国工程物理研究院激光聚变研究中心 极端条件物质特性联合实验室, 四川 绵阳 621900)

\begin{abstract}
摘 要: 研究了不同球磨时间条件下 CNTs 辅助球磨对 Zr 粉形貌和氧化性能的影响。采用 XRD 和 SEM 分析了球磨过程中 Zr 粉的物相 组成和形貌演变, 采用热重 ( TG ) 法评估了 $\mathrm{Zr}$ 粉的氧化性能。结果表明: 添加 CNTs 辅助球磨对 $\mathrm{Zr}$ 粉的物相组成没有影响, 但是会影 响 $\mathrm{Zr}$ 粉的形貌和氧化性能。不添加 CNTs 时, 随着球磨时间的增加 (1 3 h ), Zr 粉粒径持续减小, 球磨 $3 \mathrm{~h}$ 后, $\mathrm{Zr}$ 粉粒径由十几微米减 小到 2 3 $\mu \mathrm{m}$ 。添加 CNTs 辅助球磨后, Zr 粉的颗粒细化过程滞后, 球磨初期 (1 2 h ), Zr 粉粒径没有显著变化, 直到球磨时间延长到 3 $\mathrm{h}$ 时, $\mathrm{Zr}$ 粉粒径才开始明显减小。这是因为 CNTs 在 $\mathrm{Zr}$ 颗粒表面的黏附和 CNTs 在 $\mathrm{Zr}$ 粉中的团聚阻碍了磨球对 $\mathrm{Zr}$ 颗粒的机械冲击和破 碎作用。与直接球磨 $\mathrm{Zr}$ 粉相比, 当所得 $\mathrm{Zr}$ 粉粒径相差不大时, 添加 CNTs 辅助球磨使 $\mathrm{Zr}$ 粉的起始氧化温度和峰值氧化温度降低了 $11 \sim 37{ }^{\circ} \mathrm{C}$, 这是因为 $\mathrm{CNTs}$ 的良好导热性促进了 $\mathrm{Zr}$ 粉氧化过程中的传热。另一方面, 球磨时间少于 $2 \mathrm{~h}$ 时, $\mathrm{Zr} / \mathrm{CNTs}$ 混合物中 $\mathrm{Zr}$ 粉的 氧化增重量比纯 $\mathrm{Zr}$ 粉的增重量略有降低, 但球磨时间超过 $2 \mathrm{~h}$ 时, 这种趋势出现反转。前者是因为短时间球磨时, CNTs 引起 Zr 粉的 局部团聚, 阻碍了团聚体中 $\mathrm{Zr}$ 粉与氧气的接触, 并且混合物中的 $\mathrm{Zr}$ 粉颗粒还没有被明显细化, 这都降低了 $\mathrm{Zr}$ 粉的氧化程度; 随后的 反转趋势是因为球磨时间增加后, 混合物中的 $\mathrm{Zr}$ 粉开始明显细化, 促进了其氧化反应的进行, 但是纯 $\mathrm{Zr}$ 粉由于颗粒尺寸提前细化而发 生了显著的自发氧化, 降低了活性 $\mathrm{Zr}$ 的含量。
\end{abstract}

关键词: Zr 粉; 球磨; CNTs; 形貌; 氧化

作者简介: 康晓丽, 女, 1984 年生, 博士, 副研究员, 中国工程物理研究院激光聚变研究中心, 四川 绵阳 621900, 电话: 0816-2480903, E-mail: kangxiaoli515@126.com 